\title{
Functional polymorphisms in asporin and $C I L P$ together with joint loading predispose to hand osteoarthritis
}

\author{
Mari Taipale ${ }^{1,2}$, Svetlana Solovieva $^{3}$, Päivi Leino-Arjas ${ }^{3}$ and Minna Männikkö ${ }^{1,2^{*}}$ (D)
}

\begin{abstract}
Background: Osteoarthritis $(\mathrm{OA})$ is the most common degenerative joint disease afflicting people in the Western world and has a strong genetic influence. The aim of this study was to examine the association of two known functional polymorphisms in the TGF- $\beta$ inhibiting genes, asporin (ASPN) and cartilage intermediate layer protein (CILP), with hand OA and potential gene-occupational hand loading interaction.

Results: Statistically significant interaction of the CILP rs2073711 T and ASPN D15 alleles with hand OA was observed $(\mathrm{OR}=2.48,95 \% \mathrm{Cl} 1.27-4.85, p=0.008)$ in a Finnish hand OA cohort of 543 women (aged 45-63). When stratified by variation in working tasks, low variation of working tasks increased the risk further $(\mathrm{OR}=3.00,95 \% \mathrm{Cl} 1.35-6.66, p=0$. 007). Based on the analysis of ASPN and CILP protein-coding regions, functional studies were performed with one observed variant, rs41278695 in the ASPN gene. Analyses showed that bone morphogenetic protein 2 (BMP2) mediated expression of aggrecan (AgC1) and type II collagen (Col2a1) was significantly suppressed ( $p=0.011$ and $p=0.023$, respectively) in a murine chondrocytic cell line (ATDC5) with cells stably expressing ASPN rs41278695.

Conclusions: The carriage of either ASPN D15 or CILP rs2073711 TT is associated with increased risk of symmetrical hand OA, particularly in individuals with low variation in work tasks. ASPN rs41278695 SNP had an effect on Agc1 and Col2a1 gene expression when induced with BMP-2 suggesting an effect on the cartilage extracellular matrix composition.
\end{abstract}

Keywords: Osteoarthritis, Asporin, Cartilage intermediate layer protein, Genetic association, Functional variant

\section{Background}

Osteoarthritis $(\mathrm{OA})$ is a joint disorder involving degeneration of the cartilage, but also affecting surrounding tissues [1]. OA disables often weight-bearing joints such as hip and knee, but the most frequent site is in the hand, particularly among women over 50 years of age [2]. Between $39 \%$ to $65 \%$ of the hand and knee OA in women are associated with genetic factors [3]. Despite numerous studies, only a few susceptibility genes have been identified and replicated [4]. A physiological range of mechanical loading is required for the maintenance of healthy cartilage homoeostasis [5]. Overloading as well as reduced loading increases cartilage matrix degeneration $[6,7]$.

\footnotetext{
*Correspondence: minna.mannikko@oulu.fi

${ }^{1}$ Center for Life Course Health Research, Faculty of Medicine, University of Oulu, Aapistie 5, 90220 Oulu, Finland

${ }^{2}$ Biocenter Oulu and Faculty of Faculty of Biochemistry and Molecular

Medicine, University of Oulu, Oulu, Finland

Full list of author information is available at the end of the article
}

Non-physiological joint loading regulates gene expression including the matrix-degrading enzymes such as the matrix metalloproteinases (MMPs) [8]. A study done with human mesenchymal stem cells demonstrated that gene regulation induced by mechanical loading is mediated through the transforming growth factor beta (TGF- $\beta$ ) pathway [9].

Members of the TGF- $\beta$ superfamily play an important role in controlling the proliferation and differentiation of articular cartilage chondrocytes [10]. In addition, TGF- $\beta$ has a crucial role in the formation of osteophytes, bony outgrowths at the margins of the joint [11]. This growth factor family includes also bone morphogenetic proteins (BMPs), activins, inhibins, and growth and differentiation factors (GDFs) [12]. Recently, Hämäläinen et al. reported a strong association between the TGFB1 gene (transforming growth factor beta 1) and symptomatic DIP (distal interphalangeal) OA [13]. Both asporin (ASPN) and cartilage intermediate layer protein (CILP) 
have been shown to inhibit TGF- $\beta$ mediated signaling by direct binding [14-16].

Asporin is a member of the class I subfamily of small leucine rich proteoglycans (SLRPs) although it is not a proteoglycan. It has a unique aspartic acid (D) repeat in its amino-terminal end and its expression is increased in OA $[17,18]$. In addition, asporin differs from other SLRPs in relation to the ability to induce biomineralization of collagen by its calcium-binding $\mathrm{D}$ repeat and Cterminal collagen-binding domain [19]. ASPN D-repeat polymorphism has been associated with OA, lumbar disc degeneration (LDD) and developmental dysplasia of the hip (DDH) $[14,20,21]$. The association with OA has been replicated in small-scale studies [22-24], but several Caucasian based studies failed to replicate the association, [22, 25-27] and meta-analysis combining the data from different association studies demonstrated ethnic differences [28]. Functional studies on the ASPN D14 allele showed that it more greatly inhibits the TGF$\beta$ mediated expression of the aggrecan (AGC1) and collagen II (COL2A1) genes, the marker genes for chondrogenesis, than other alleles [14].

CILP is an extracellular matrix glycoprotein with a thrombospondin (TSP) type 1 repeat domain and its precursor protein encodes a homologue to porcine Nucleotide pyrophosphohydrolase (NTPPHase) in its carboxy-terminal portion. The expression of CILP increases with age $[29,30]$. A functional single nucleotide polymorphism (SNP) in CILP (c.1184 T > C, rs2073711) resulting in amino acid substitution Ile395Thr is associated with lumbar disc degeneration (LDD), and the $1184 \mathrm{C}$ allele has a stronger inhibitory effect on TGF- $\beta 1$ signaling [15]. CILP haplotype was also shown to associate with knee OA in men in one study [31].

Our aim was to study whether two known functional polymorphisms in the TGF- $\beta$ inhibiting genes, ASPN and CILP, are associated with hand OA among women. In addition, we searched for new putative OA predisposing variants in these genes and studied in vitro the functional significance of one rare $A S P N$ sequence variant that had clinical relevance. Finally, we explored the potential interaction between genetic predisposition and occupational hand loading.

\section{Methods}

\section{Study population}

The study material was comprised of two randomly selected samples of female dentists $(n=295)$ and teachers $(n=248)$ aged 45 to 63 years [32]. Mean age of the dentists and teachers did not differ statistically significantly: 54 years (SD 6, range $45-63$ ) vs. 54 years (SD 4, range 45-61), respectively $(p=0.99)$. These occupational groups were chosen because of the similar socio-economic status, but different hand loading involved in daily work. The dentists have continuous and extensive manual workload that causes strain on hands and fingers, whereas the occupational description of teachers does not include straining to the joints. All individuals were living in Helsinki or its neighboring towns. They gave signed informed consent, and local ethics committee approved the study.

\section{Clinical and radiological assessments}

Both hands of the participants were radiographed to evaluate the distal interphalangeal (DIP), proximal interphalangeal (PIP), thumb interphalangeal (IP) and metacarpophalangeal (MCP) joints of both hands by an experienced radiologist blinded to all the data regarding the subjects (occupation, age, and health data). Joints were evaluated for the presence of OA using a modified Kellgren and Lawrence (K-L) system [33] the classification criteria were: grade $0=$ no $\mathrm{OA}$, grade $1=$ doubtful $\mathrm{OA}$, grade $2=$ mild $\mathrm{OA}$, grade $3=$ moderate $\mathrm{OA}$, and grade $4=$ severe OA. Participants who had symmetrical $\mathrm{OA}$ in at least two pairs of finger joints with radiographic OA of grade 2 to 4 were classified as having hand OA. Otherwise, the participants were classified as not having hand OA. Fouty-six randomly selected subjects were used for intraobserver and interobserver agreements by the same radiologist and by another experienced radiologist and they indicated good reliability [32]. Reference images have been reported in detail earlier [32].

\section{Genotyping}

ASPN D-repeat and CILP rs2073711 polymorphisms were genotyped using genomic DNA extracted from lymphocytes according to standard protocols. PCR amplifications were carried out in a volume of 11-15 $\mu \mathrm{l}$, which contained $20 \mathrm{ng}$ of genomic DNA, 3 pmol of PCR primers, $1.5 \mathrm{mM}$ of $\mathrm{MgCl} 2,0.2 \mathrm{mM}$ dNTPs and 1 unit of Supertherm Taq DNA polymerase (Medox Biotech India) or AmpliTaq Gold DNA polymerase (Applied Biosystems). Samples were analyzed using Sanger sequencing $(C I L P)$ or standard fluorescence-based genotyping methodologies (ASPN D repeat) (ABI PRISM 3100 Genetic Analyzer, Applied Biosystems). To genotype ASPN $\mathrm{D}$ repeat, amplification products were pooled and then combined with formamide and an internal size standard (GeneScan-500, Applied Biosystems). After denaturation at $90{ }^{\circ} \mathrm{C}$ for $2 \mathrm{~min}$, products were separated by size and were detected using an ABI PRISM 3100 genetic analyzer.

In addition, protein-coding regions of the $A S P N$ and CILP genes were analyzed for rare variants by Sanger sequencing (ABI PRISM 3100 Genetic Analyzer and BigDye terminator cycle sequencing chemistry, Applied Biosystems) in the whole study population. 


\section{Statistical analysis}

Fisher's exact probability test or the chi-square test were used to compare allele and genotype frequencies between dentists and teachers. Fisher's exact test was chosen when the observed values were small in the individual groups, especially when comparing allele frequencies in the contingency tables. The association between the ASPN repeat polymorphism and CILP rs2073711 genotypes (CC, CT and TT) with hand OA was studied with a set of logistic regression analyses. The dependent variable was symmetrical OA of grade 2 or more in at least two joint pairs and the independent variables were ASPN and CILP genotypes. Prevalence of hand OA was statistically significantly higher among teachers than among dentists $(24.7 \%$ vs. $17.0 \%, p=0.03)$ and therefore age and occupation were included in the model as potential confounders. The association of polymorphisms with hand OA was also examined for dentists and teachers separately. A $p$-value of $<0.05$ was considered as significant. The analyses were performed with the Statistical Package for the Social Sciences, version 12.0.1 (SPSS Inc., Chicago, IL, USA).

\section{ASPN constructs}

ASPN cDNA was amplified using Human Ovary Marathon-Ready cDNA (Clontech) as a template. PCR primers included recognition sequences for BamHI and XhoI restriction enzymes (primer sequences are available on request). The amplified PCR product was ligated into pcDNA3.1(+) expression vector (Invitrogen). The mutant ASPN construct was generated using QuikChange Site-Directed Mutagenesis Kit (Stratagene) according to the manufacturer's instructions. Primer sequences used in mutagenesis are available on request.

\section{Cell culture and transfections}

A murine chondrocytic cell line (ATDC5) was purchased from RIKEN Cell Bank, Tsukuba Japan. ATDC5 cells were cultured in 1:1 mixture of Dulbecco's modified Eagle's medium (DMEM; Biochrom KG, Berlin, Germany) and Ham's F-12 nutrient mixture supplemented with $5 \%(v / v)$ fetal bovine serum (FBS; GB Perbio HyClone, Cheshire, UK), $10 \mu \mathrm{g} / \mathrm{ml}$ human transferrin (Sigma), $3 \times 10^{-8} \mathrm{M}$ sodium selenite (Sigma), $0.1 \%$ penicillin (Sigma, St Louis, MO), 0.01\% Fungizone (Cambrex Bio Science, Walkersville, MD), 0.1\% L-glutamate (Sigma) and $5 \% \mathrm{Na}$-bicarbonate (Sigma) at $37{ }^{\circ} \mathrm{C}$ under $5 \% \mathrm{CO}_{2}$.

For transient transfections $3.5 \times 10^{5}$ cells were plated on 6-well plates and cultured in maintenance medium with ITS (Sigma; $10 \mu \mathrm{g} / \mathrm{ml}$ insulin, $10 \mu \mathrm{g} / \mathrm{ml}$ transferrin and $3 \times$ $10^{-8} \mathrm{M}$ sodium selenite). After $24 \mathrm{~h}$ cells were transfected with ASPN wild type (wt) or mutant construct using Lipofetamine and Plus-reagent (Invitrogen) according to manufacturer's instructions. Empty pcDNA3.1 (+) was used as a negative control, and $2 \mu \mathrm{g}$ DNA, $3 \mu \mathrm{l}$ Lipofectamine and $10 \mu \mathrm{l}$ Plus-reagent were used. Forty-eight hours after transfections medium was changed to DMEM-F12 (1:1) supplemented with $0.2 \%$ FBS and ITS. Twelve hours after the medium change cells were treated with $10 \mathrm{ng} / \mathrm{ml}$ TGF- $\beta 1$ (Chemicon) for $16 \mathrm{~h}$ or six hours after medium change with $100 \mathrm{ng} / \mathrm{ml}$ BMP-2 (ProSpec) for $12 \mathrm{~h}$. Each experiment was performed in sextuple and repeated three times.

For generating stable cell line expressing wt or mutant ASPN $3.5 \times 10^{5}$ cells were plated on a 6 -well plate and cultured in the maintenance medium for $24 \mathrm{~h}$. Cells were transfected with $A S P N$ wt or mutation construct using Lipofetamine and Plus-reagent as described earlier. Empty pcDNA3.1 (+) was used as a negative control. After $24 \mathrm{~h}$ the medium was replaced with fresh maintenance medium supplemented with $500 \mu \mathrm{g} / \mathrm{ml}$ Geneticin, G418 (Sigma). The selection medium was changed every second day until cells without the neomycin resistance gene on the control plate were killed. After 11d, cells were diluted and plated on a 96-well plate. Selection of single colony cells was done using serial dilution.

Clones stably expressing wt or mutant $A S P N$, and a clone with an empty pcDNA3.1 (+) vector were cultured in maintenance medium with $500 \mu \mathrm{g} / \mathrm{ml} \mathrm{G418} \mathrm{until} \mathrm{they}$ reached confluence. After that $3.5 \times 10^{5}$ cells were plated on a 6 -well plate. After $24 \mathrm{~h}$ the standard medium was supplemented with ITS and $50 \mu \mathrm{g} / \mathrm{ml}$ ascorbic acid. After $24 \mathrm{~h}$ the cells were treated with $10 \mathrm{ng} / \mathrm{ml}$ TGF- $\beta 1$, $100 \mathrm{ng} / \mathrm{ml} \mathrm{BMP-2}$ or without any growth factor for $24 \mathrm{~h}$. Each experiment was performed in sextuple and two independent clones for each asporin variant were used.

Real-time quantitative polymerase chain reaction (qPCR) Total RNA was extracted from cells using E.Z.N.A Total RNA Kit (Omega Bio-Tek) with RNase-free DNase (Omega Bio-Tek) treatment and cDNA was synthesized using iScript cDNA Synthesis Kit (Bio-Rad). Real-time qPCR was carried out in duplicate using iTaq SYBR Green Supermix with ROX kit (Bio-Rad) in accordance with the manufacturer's instructions in an MXPro 3005 machine (Stratagene). Gapdh (glyceraldehyde 3-phosphate dehydrogenase) was used as the reference gene. Sequences of oligonucleotide primers used in real-time qPCR amplification are available on request.

\section{Results}

\section{Association of ASPN D repeat and CILP rs207371}

The ASPN and CILP variants were analyzed in a sample of Finnish women from two occupational groups (295 dentists and 248 teachers). Genotyping of both variants were successful from 524 women. The allelic frequencies of the $A S P N$ D repeat and CILP rs2073711 polymorphisms are 
summarized in Table 1. The ASPN D15 allele was overrepresented in the teachers as compared with the dentists (Fisher's exact probability test, $p=0.007$ ) and therefore stratification of the data by occupation was used in the analyses. Dentists carrying at least one ASPN D15 allele or CILP rs2073711 TT had an increased risk for hand OA $(\mathrm{OR}=2.48,95 \% \mathrm{CI} 1.27-4.85, p=0.008)$ compared to teachers (Table 2). When stratified by variation in dental tasks, low variation of dental tasks increased the risk further $(\mathrm{OR}=3.00,95 \%$ CI 1.35-6.66, $p=0.007)$ (Table 2). There was a synergetic effect of joint overuse and having either ASPN D15 or CILP rs2073711 TT on the risk of symmetrical hand $\mathrm{OA}$ when analyzing dentists only $(\mathrm{OR}=3.30$, 95\% CI 1.18-9.20, $p=0.02$ ) (Table 3).

\section{Rare coding variants}

Coding sequences and exon-intron boundaries of the $A S P N$ and CILP genes were analyzed in the whole study population to find rare variants. A missense SNP causing a Gly193Glu change in the fourth exon of ASPN was found in ten individuals (1.8\%). Because of the low frequency, our sample set was not sufficient for association analyses. The clinical status of the variant carriers was evaluated more closely. Seven of the ten individuals had osteophytes or at least grade $2+\mathrm{OA}$ in at least one finger joint. The remaining three individuals did not have OA or any chronic diseases diagnosed by the physician, but at the time of the enrollment they all had reported pain in the joints of the fingers during the past

Table 1 Allelic frequencies of the ASPN D repeat and CILP rs2073711 polymorphisms

\begin{tabular}{|c|c|c|c|c|c|c|}
\hline \multirow[t]{2}{*}{ Alleles } & \multicolumn{2}{|c|}{ All $(N=524)$} & \multicolumn{2}{|c|}{ Dentists $(N=285)$} & \multicolumn{2}{|c|}{ Teachers $(N=239)$} \\
\hline & N (cases) & $\%$ & N (cases) & $\%$ & $N$ (cases) & $\%$ \\
\hline \multicolumn{7}{|l|}{ ASPN D repeat } \\
\hline D12 & $23(2)$ & 2.2 & $14(1)$ & 2.5 & $9(1)$ & 1.9 \\
\hline D13 & 555 (114) & 53.0 & $310(45)$ & 54.4 & $245(69)$ & 51.3 \\
\hline D14 & $172(35)$ & 16.4 & $101(20)$ & 17.7 & $71(15)$ & 14.9 \\
\hline D15 & $190(46)$ & 18.1 & $86(21)$ & 15.1 & $104(25)$ & 21.8 \\
\hline D16 & $65(11)$ & 6.2 & $33(4)$ & 5.8 & $32(7)$ & 6.7 \\
\hline D17 & $26(4)$ & 2.5 & $18(3)$ & 3.2 & $8(1)$ & 1.7 \\
\hline D18 & $17(2)$ & 1.6 & $8(2)$ & 1.4 & $9(0)$ & 1.9 \\
\hline \multirow[t]{2}{*}{ CILP rs2073711 } & \multicolumn{2}{|c|}{ All $(N=529)$} & \multicolumn{2}{|c|}{ Dentists $(N=288)$} & \multicolumn{2}{|c|}{ Teachers $(N=241)$} \\
\hline & N (cases) & $\%$ & N (cases) & $\%$ & $N$ (cases) & $\%$ \\
\hline $\mathrm{T}$ & $435(92)$ & 41.1 & $233(42)$ & 40.4 & $202(50)$ & 41.9 \\
\hline C & $623(124)$ & 58.9 & $343(54)$ & 59.6 & $280(70)$ & 58.1 \\
\hline $\mathrm{CC}$ & $180(33)$ & 34.0 & $106(17)$ & 36.6 & $74(16)$ & 30.7 \\
\hline $\mathrm{CT}$ & $263(58)$ & 48.4 & $131(20)$ & 45.5 & $132(38)$ & 54.8 \\
\hline$\pi$ & $86(17)$ & 16.3 & $51(11)$ & 17.7 & $35(6)$ & 14.5 \\
\hline
\end{tabular}

Fisher's exact probability test was used to compare allele frequencies between dentists and teachers and a chi-square test was used to compare genotype frequencies between dentists and teachers
30 days, two had reported wrist pain during the past 12 months and one had shoulder pain, one neck pain and two had low back pain during the past 12 months. This variant (rs41278695) has been annotated in the 1000 genome project with minor allele frequency of less than 0.01 . Tomoeda et al. has showed that rs 41278695 inhibits BMP-2 signaling in periodontal ligament (PDL) cells [16]. Based on the patients' status and suggestion on its functionality, rs41278695 was chosen for functional assays.

\section{Functional significance of rs41278695}

The effect of ASPN rs 41278695 on the TGF- $\beta 1$ mediated expression of aggrecan and collagen II was studied. Expression levels of $A g c 1$ and Col2a1 was measured in ATDC5 cells transfected with wt or mutant ASPN construct and treated with TGF- $\beta 1$ or BMP2. Expression of $A g c 1$ and Col2a1 was not changed between ATDC5 cells transiently transfected with wt ASPN or mutant $A S P N$ expressing plasmids (data not shown). Also, there was no difference when TGF- $\beta 1$ or BMP2 was used as an inducer. However, $A g c 1$ and Col2a1 expression was suppressed ( $p=0.011$ and $p=0.023$, respectively) in ATDC5 cells stably expressing mutant ASPN compared to cells expressing wt ASPN (Fig. 1). This was noticed only when BMP2 was used as inducer. There was no difference in the ASPN expression between the clones.

\section{Discussion}

In the present study, we demonstrate that there is a synergetic effect of joint overuse and genetic variants on the risk of symmetrical hand OA. Dentists having either ASPN D15 or CILP rs2073711 TT and having low variation of dental tasks had increased risk for hand OA. Our study also supports previous findings that ASPN is a regulator of BMP-2 mediated activation of chondrogenesis.

In previous studies, ASPN D14, instead of D15, was associated with knee OA, especially in studies performed in Asian populations [14, 23, 24]. However, a Greek study demonstrated an association between D15 allele and knee OA [26], which is consistent with our finding. Contrary to the study of Kizawa et al., the protective role of ASPN D13 was not seen in the present study. To the best of our knowledge, this is the first study that shows the association between ASPN D-repeat and hand OA.

Our findings suggest that CILP rs2073711 TT is associated with increased risk of symmetrical hand OA together with ASPN D15 allele. The CILP rs2073711 TT genotype was associated with disc degeneration (DD) in a Finnish study [34]. In addition, CILP rs2073711 genotype $\mathrm{CC}$ was shown to associate with lower radiographic progression of OA in a UK study [35]. However, contradictory results were obtained in a Japanese casecontrol study, which showed an association between the 
Table 2 Association of ASPN D repeat and CILP rs2073711 polymorphism with hand OA

\begin{tabular}{lllll}
\hline $\begin{array}{l}\text { ASPN D15 \& CILP } \\
\text { rs2073711 }\end{array}$ & $\begin{array}{l}\text { N } \\
\left(\text { cases }^{\mathrm{a}}\right)\end{array}$ & OR (95\% Cl) & $\begin{array}{l}\text { Stratified by occupation } \\
\text { Dentists / Teachers } \\
\text { OR (95\% Cl) }\end{array}$ & $\begin{array}{l}\text { Stratified by variation in dental tasks (dentists only) - } \\
\text { Low variation } \\
\text { OR (95\% Cl) }\end{array}$ \\
\hline No D15 \& CC + CT & $300(54)$ & 1.0 & 1.0 & 1.0 \\
At least one D15 or TT & $224(53)$ & $\begin{array}{l}1.43(0.92-2- \\
23)\end{array}$ & $\begin{array}{l}2.48(1.27-4.85), p=0.008^{C} / 0.91(0.50-1.67), \\
p=0.77\end{array}$ & $3.00(1.35-6.66), p=0.007^{d}$
\end{tabular}

Logistic regression analysis; $\mathrm{Cl}$, confidence interval; OR, odds ratio

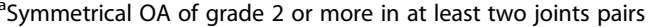

${ }^{\mathrm{b}}$ Adjusted for age (years) and occupation

'Bonferroni corrected $p=0.04$

Bonferroni corrected $p=0.035$

CILP rs2073711 C allele and LDD [15]. Seki et al. also demonstrated that $C$ allele of CILP rs2073711 showed increased binding and inhibition of TGF- $\beta$ signaling. It has been indicated in several association studies that there are ethnic differences between Asian and Caucasian populations [28, 36-40]. For instance, allele frequency of CILP rs2073711 C is more common in Europeans than in Asians (The NCBI dbSNP database) and both alleles of certain polymorphisms have been associated with osteoporosis and gastric cancer among different racial groups [41-43]. One explanation is that the alleles are in a different haplotype blocks in different populations and the other factors define if the allele has a harmful or protective role in a population [44].

While physiological range of mechanical loading maintains cartilage homeostasis, both reduced loading and overloading shift the metabolic reactions to favor catabolism over anabolism [6]. It has been shown that low variation in work tasks, for example in dental tasks, is a risk factor for finger OA [45]. We observed the same phenomenon in the present study. When the results were stratified by variation in dental tasks, the risk for finger OA was increased in women having either ASPN D15 or CILP rs2073711 TT genotype and low variation in joint usage. Hämäläinen et al. used the same hand OA cohort in their study and showed that COL2A1 gene polymorphisms may play a role in the aetiology of hand OA together with repetitive loading work tasks [46]. One limitation of our study was in its modest sample size for a genetic study of a complex disease. It has however the advantage that the study subjects were well characterized for their OA status and the use of hand joints. Our results presented here further supports the hypothesis that mechanical stress such as joint loading has an effect on the expression of cartilage matrix genes [47] and thus regulates the gene expression together with genetic variations.

In addition, we identified a rare missense SNP rs41278695 resulting in an amino acid change Gly193Glu in the human ASPN gene among hand OA patients with osteophytes. This sequence variation is located at the fifth leucine rich repeat (LRR5) of asporin. Asporin binds directly to TGF- $\beta$ and binding is mediated through amino acids 159-205 [48]. This sequence also contributes the induction of collagen II and aggrecan gene expression [48]. According to our results, Gly193Glu had an effect on $A g c 1$ and Col2a1 gene expression when induced with BMP-2. This effect was not shown when we used TGF- $\beta 1$ as an inducer. There was relative high variation in the measurements of the biological replicates especially for the wt, but our finding is consistent with an earlier study by Tomoeda et al., which showed that asporin inhibits BMP-2 signaling via LRR5 and Glu-194 (the amino acid numbering depends on the $\mathrm{D}$ repeat length) plays critical role in the interaction [16]. As well as asporin other genes which belong to TGF- $\beta$ signaling pathway are associated with osteoarthritis, including GFD5 [49-53] and SMAD3 [54, 55].

Our study suggests that combinations of variants in the ASPN and CILP gene, which both act in the TGF- $\beta$ pathway, possibly have an additive effect in the development of hand OA. The combinatorial

Table 3 Joint effect of ASPN D15 and CILP TT variations, and variation in dental task among dentists in relation to hand OA

\begin{tabular}{|c|c|c|c|c|}
\hline \multirow{2}{*}{$\begin{array}{l}\text { ASPN D15 \& } \\
\text { CILP rs2073711 }\end{array}$} & \multirow{2}{*}{$\begin{array}{l}\text { Variation in } \\
\text { dental tasks }\end{array}$} & \multicolumn{3}{|c|}{ Symmetrical OA in at least two joint pairs } \\
\hline & & $\mathrm{N}$ (cases) & OR $(95 \% \mathrm{Cl})^{\mathrm{a}}$ & $p$-value \\
\hline No D15 \& CC + CT & diversity of tasks & $58(6)$ & 1.0 & \\
\hline No D15 \& CC + CT & low variation & $109(15)$ & $1.14(0.40-3.25)$ & 0.80 \\
\hline At least one D15 or $\pi$ & diversity of tasks & $35(5)$ & $1.91(0.50-7.25)$ & 0.34 \\
\hline At least one D15 or TT & low variation & $77(22)$ & $3.30(1.18-9.20)$ & 0.02 \\
\hline
\end{tabular}

Logistic regression analysis, $\mathrm{Cl}$, confidence interval; $\mathrm{OR}$, odds ratio

${ }^{a}$ Adjusted for age (years) 

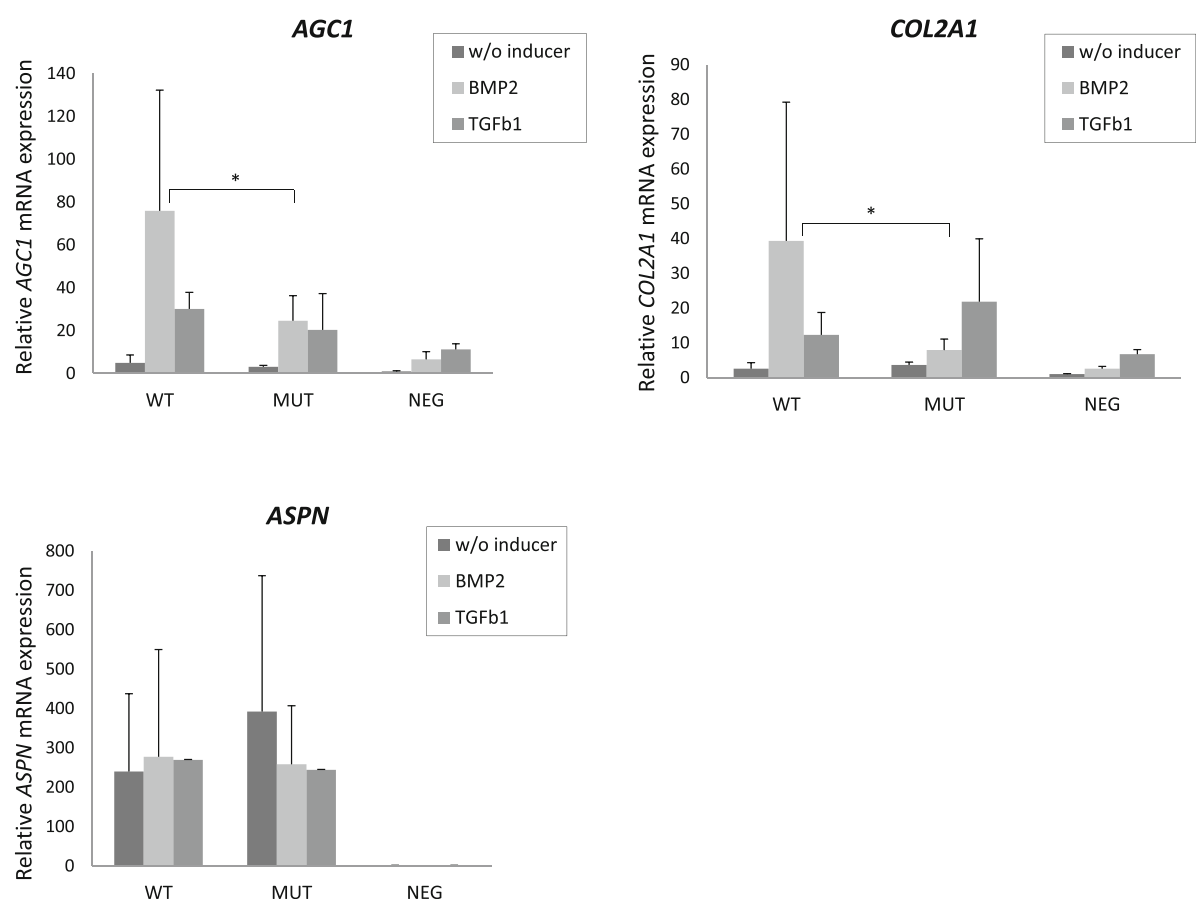

Fig. 1 Effect of the stable overexpression of wt ASPN (WT) and ASPN-193Glu (MUT) on the expression of cartilage marker genes during chondrogenic differentiation of ATDC5 cells. Error bars represent standard deviation of six biological replicates of two independent clones

effect between $A S P N$ and CILP suggests a cross-talk between these two genes. This effect is enhanced by high loading of joints. This is the first study that shows association between ASPN D repeat and CILP rs2073711 polymorphisms and hand OA. The in vitro studies of the Gly193Glu amino acid change further supports the important role of rare variants in common diseases such as osteoarthritis. In complex diseases, like in osteoarthritis, several loci have been associated with the disease in large-scale genomewide association studies (GWAS) [56, 57]. Common SNPs have only small effect sizes and thus are not likely to play a major role in development of the disease. Rare variants, however, account for a greater faction of familial clustering of common diseases, and have a strong impact on the disease risk [58]. Taken together variants in the TGF- $\beta$ signaling pathway molecules seem to play a major role in the development of $\mathrm{OA}$ and joint loading enhances the effect. Thus modulation of TGF- $\beta$ signaling pathway may be a potential therapeutic target for osteoarthritis.

\section{Conclusions}

The present study provides further evidence for the role of $A S P N$ and CILP polymorphisms in the etiology of OA. This effect was further increased by mechanical hand loading supporting the hypothesis of gene - environmental interaction as part of the etiology in hand OA.

\section{Abbreviations}

ASPN: Asporin; BMP: Bone morphogenetic protein; Cl: Confidence interval; CILP: Cartilage intermediate layer protein; D: Aspartic acid;

DDH: Developmental dysplasia of the hip; DIP: Distal interphalangeal; DMEM: Dulbecco's modified Eagle's medium; FBS: Fetal bovine serum; Gapdh: Glyceraldehyde 3-phosphate dehydrogenase; GDF: Differentiation factor; Glu: Glutamic acid; Gly: Glycine; IP: Thumb interphalangeal; ITS: Insulintransferrin-sodium selenite; K-L: Kellgren and Lawrence; LDD: Lumbar disc degeneration; MCP: Metacarpophalangeal; MMP: Matrix metalloproteinase; NTPPHase: Nucleotide pyrophosphohydrolase; OA: Osteoarthritis; OR: Odds ratio; p: P-value; PIP: Proximal interphalangeal; SLRP: Small leucine rich proteoglycan; SNP: Small nucleotide polymorphism; TGF- $\beta$ : Transforming growth factor beta; TSP: Thrombospondin; WT: Wild type

\section{Acknowledgements}

We would like to thank all the individuals for participating in the study. We thank Minna Kraatari, MD, for her valuable help in the generation of stable cell lines. Laboratory technicians Anu Myllymäki and Aira Erkkilä are thanked for their excellent technical assistance.

\section{Funding}

Not applicable.

\section{Availability of data and materials}

Raw data can be obtained from the Finnish Institute of Occupational Health (P. Leino-Arjas) by request.

\section{Authors' contributions}

MT designed the study, carried out molecular genetic studies and drafted the manuscript. SL performed the statistical analyses and contributed to the interpretation of data. PLA, SL and MM conceived the study and participated in its design. MM contributed to the interpretation of data and writing the manuscript. All authors read and approved the manuscript.

\section{Ethics approval and consent to participate}

All individuals who participated in this study gave their written informed consent, and The Hospital District of Helsinki and Uusimaa Ethics Committee for Research in Occupational Health and Safety approved the study. 


\section{Consent for publication}

Not applicable.

\section{Competing interests}

The authors declare that they have no competing interests.

\section{Publisher's Note}

Springer Nature remains neutral with regard to jurisdictional claims in published maps and institutional affiliations.

\section{Author details}

${ }^{1}$ Center for Life Course Health Research, Faculty of Medicine, University of Oulu, Aapistie 5, 90220 Oulu, Finland. ${ }^{2}$ Biocenter Oulu and Faculty of Faculty of Biochemistry and Molecular Medicine, University of Oulu, Oulu, Finland. ${ }^{3}$ Department of Epidemiology and Biostatistics, Centre of Expertise for Health and Work Ability, Finnish Institute of Occupational Health, Helsinki, Finland.

Received: 24 January 2017 Accepted: 7 December 2017

Published online: 12 December 2017

\section{References}

1. Litwic A, Edwards MH, Dennison EM, Cooper C. Epidemiology and burden of osteoarthritis. Br Med Bull. 2013;105:185-99.

2. Kalichman L, Hernandez-Molina G. Hand osteoarthritis: an epidemiological perspective. Semin Arthritis Rheum. 2010;39(6):465-76.

3. Spector TD, Cicuttini F, Baker J, Loughlin J, Hart D. Genetic influences on osteoarthritis in women: a twin study. BMJ. 1996;312(7036):940-3.

4. Tsezou A. Osteoarthritis year in review 2014: genetics and genomics. Osteoarthr Cartil. 2014;22(12):2017-24

5. Ikenoue T, Trindade MC, Lee MS, Lin EY, Schurman DJ, Goodman SB, Smith RL. Mechanoregulation of human articular chondrocyte aggrecan and type II collagen expression by intermittent hydrostatic pressure in vitro. J Orthop Res. 2003;21(1):110-6.

6. Sun HB. Mechanical loading, cartilage degradation, and arthritis. Ann N Y Acad Sci. 2010;1211:37-50.

7. Yokota H, Leong DJ, Sun HB. Mechanical loading: bone remodeling and cartilage maintenance. Curr Osteoporos Rep. 2011:9(4):237-42.

8. Lee JH, Fitzgerald JB, DiMicco MA, Grodzinsky AJ. Mechanical injury of cartilage explants causes specific time-dependent changes in chondrocyte gene expression. Arthritis Rheum. 2005;52(8):2386-95.

9. Li Z, Kupcsik L, Yao S, Alini M, Stoddart MJ. Mechanical load modulates chondrogenesis of human mesenchymal stem cells through the TGF- $\beta$ pathway. J Cell Mol Med. 2010;14(6a):1338-46.

10. Grimaud E, Heymann D, Redini F. Recent advances in TGF-beta effects on chondrocyte metabolism. Potential therapeutic roles of TGF-beta in cartilage disorders. Cytokine Growth Factor Rev. 2002;13(3):241-57.

11. van der Kraan PM, Goumans MJ, Blaney Davidson E, ten Dijke P. Agedependent alteration of TGF-beta signalling in osteoarthritis. Cell Tissue Res. 2012;347(1):257-65.

12. de Caestecker M. The transforming growth factor-beta superfamily of receptors. Cytokine Growth Factor Rev. 2004;15(1):1-11.

13. Hämäläinen S, Solovieva S, Vehmas T, Luoma K, Leino-Arjas P, Hirvonen A Genetic influences on hand osteoarthritis in Finnish women-a replication study of candidate genes. PLoS One. 2014;13:9(5).

14. Kizawa H, Kou I, lida A, Sudo A, Miyamoto Y, Fukuda A, Mabuchi A, Kotani A, Kawakami A, Yamamoto S, Uchida A, Nakamura K, Notoya K, Nakamura Y, Ikegawa S. An aspartic acid repeat polymorphism in asporin inhibits chondrogenesis and increases susceptibility to osteoarthritis. Nat Genet. 2005;37(2):138-44

15. Seki S, Kawaguchi Y, Chiba K, Mikami Y, Kizawa H, Oya T, Mio F, Mori M, Miyamoto Y, Masuda I, Tsunoda T, Kamata M, Kubo T, Toyama Y, Kimura T, Nakamura Y, Ikegawa S. A functional SNP in CILP, encoding cartilage intermediate layer protein, is associated with susceptibility to lumbar disc disease. Nat Genet. 2005;37(6):607-12

16. Tomoeda M, Yamada S, Shirai H, Ozawa Y, Yanagita M, Murakami S. PLAP-1/ asporin inhibits activation of BMP receptor via its leucine-rich repeat motif. Biochem Biophys Res Commun. 2008;371(2):191-6

17. Henry SP, Takanosu M, Boyd TC, Mayne PM, Eberspaecher H, Zhou W, de Crombrugghe B, Hook M, Mayne R. Expression pattern and gene characterization of asporin. A newly discovered member of the leucine-rich repeat protein family. J Biol Chem. 2001;276(15):12212-21.
18. Lorenzo P, Aspberg A, Onnerfjord P, Bayliss MT, Neame PJ, Heinegard D. Identification and characterization of asporin. A novel member of the leucine-rich repeat protein family closely related to decorin and biglycan. J Biol Chem. 2001;276(15):12201-11.

19. Kalamajski S, Aspberg A, Lindblom K, Heinegard D, Oldberg A. Asporin competes with decorin for collagen binding, binds calcium and promotes osteoblast collagen mineralization. Biochem J. 2009;423(1):53-9.

20. Song YQ, Cheung KM, Ho DW, Poon SC, Chiba K, Kawaguchi Y, Hirose Y, Alini M, Grad S, Yee AF, Leong JC, Luk KD, Yip SP, Karppinen J, Cheah KS, Sham P, Ikegawa S, Chan D. Association of the asporin D14 allele with lumbar-disc degeneration in Asians. Am J Hum Genet. 2008;82(3):744-7.

21. Shi D, Dai J, Zhu P, Qin J, Zhu L, Zhu H, Zhao B, Qiu X, Xu Z, Chen D, Yi L, Ikegawa $S$, Jiang $Q$. Association of the $D$ repeat polymorphism in the ASPN gene with developmental dysplasia of the hip: a case-control study in Han Chinese. Arthritis Res Ther. 2011;13(1):R27.

22. Mustafa Z, Dowling B, Chapman K, Sinsheimer JS, Carr A, Loughlin J. Investigating the aspartic acid (D) repeat of asporin as a risk factor for osteoarthritis in a UK Caucasian population. Arthritis Rheum. 2005;52(11): 3502-6.

23. Jiang Q, Shi D, Yi L, Ikegawa S, Wang Y, Nakamura T, Qiao D, Liu C, Dai J. Replication of the association of the aspartic acid repeat polymorphism in the asporin gene with knee-osteoarthritis susceptibility in Han Chinese. J Hum Genet. 2006;51(12):1068-72.

24. Shi D, Nakamura T, Dai J, Yi L, Qin J, Chen D, Xu Z, Wang Y, Ikegawa S, Jiang $\mathrm{Q}$. Association of the aspartic acid-repeat polymorphism in the asporin gene with age at onset of knee osteoarthritis in Han Chinese population. J Hum Genet. 2007;52(8):664-7.

25. Rodriguez-Lopez J, Pombo-Suarez M, Liz M, Gomez-Reino JJ, Gonzalez A. Lack of association of a variable number of aspartic acid residues in the asporin gene with osteoarthritis susceptibility: case-control studies in Spanish Caucasians. Arthritis Res Ther. 2006;8(3):R55.

26. Kaliakatsos M, Tzetis M, Kanavakis E, Fytili P, Chouliaras G, Karachalios T, Malizos K, Tsezou A. Asporin and knee osteoarthritis in patients of Greek origin. Osteoarthr Cartil. 2006;14(6):609-11.

27. Atif U, Philip A, Aponte J, Woldu EM, Brady S, Kraus VB, Jordan JM, Doherty M, Wilson AG, Moskowitz RW, Hochberg M, Loeser R, Renner JB, Chiano M. Absence of association of asporin polymorphisms and osteoarthritis susceptibility in US Caucasians. Osteoarthr Cartil. 2008;16(10):1174-7.

28. Nakamura T, Shi D, Tzetis M, Rodriguez-Lopez J, Miyamoto Y, Tsezou A, Gonzalez A, Jiang Q, Kamatani N, Loughlin J, Ikegawa S. Meta-analysis of association between the ASPN D-repeat and osteoarthritis. Hum Mol Genet. 2007;16(14):1676-81.

29. Lorenzo P, Bayliss MT, Heinegard D. A novel cartilage protein (CILP) present in the mid-zone of human articular cartilage increases with age. J Biol Chem. 1998:273(36):23463-8.

30. Lorenzo P, Neame P, Sommarin Y, Heinegard D. Cloning and deduced amino acid sequence of a novel cartilage protein (CILP) identifies a proform including a nucleotide pyrophosphohydrolase. J Biol Chem. 1998;273(36): 23469-75.

31. Valdes AM, Van Oene M, Hart DJ, Surdulescu GL, Loughlin J, Doherty M, Spector TD. Reproducible genetic associations between candidate genes and clinical knee osteoarthritis in men and women. Arthritis Rheum. 2006; 54(2):533-9.

32. Solovieva S, Vehmas T, Riihimäki H, Luoma K, Leino-Arjas P. Hand use and patterns of joint involvement in osteoarthritis. A comparison of female dentists and teachers. Rheumatology (Oxford). 2005;44(4):521-8.

33. KELLGREN JH, LAWRENCE JS. Radiological assessment of osteo-arthrosis. Ann Rheum Dis. 1957;16(4):494-502.

34. Kelempisioti A, Eskola PJ, Okuloff A, Karjalainen U, Takatalo J, Daavittila I, Niinimäki J, Sequeiros RB, Tervonen O, Solovieva S, Kao PY, Song YQ, Cheung KM, Chan D, Ala-Kokko L, Järvelin MR, Karppinen J, Männikkö M. Genetic susceptibility of intervertebral disc degeneration among young Finnish adults. BMC Med Genet. 2011;12:153.

35. Valdes AM, Hart DJ, Jones KA, Surdulescu G, Swarbrick P, Doyle DV, Schafer AJ, Spector TD. Association study of candidate genes for the prevalence and progression of knee osteoarthritis. Arthritis Rheum. 2004;50(8):2497-507.

36. Mototani H, Mabuchi A, Saito S, Fujioka M, lida A, Takatori Y, Kotani A, Kubo T, Nakamura K, Sekine A, Murakami Y, Tsunoda T, Notoya K, Nakamura Y, Ikegawa S. A functional single nucleotide polymorphism in the core promoter region of CALM1 is associated with hip osteoarthritis in Japanese. Hum Mol Genet. 2005;14(8):1009-17. 
37. Loughlin J, Sinsheimer JS, Carr A, Chapman K. The CALM1 core promoter polymorphism is not associated with hip osteoarthritis in a United Kingdom Caucasian population. Osteoarthr Cartil. 2006;14(3):295-8.

38. Miyamoto Y, Shi D, Nakajima M, Ozaki K, Sudo A, Kotani A, Uchida A, Tanaka T, Fukui N, Tsunoda T, Takahashi A, Nakamura Y, Jiang Q, Ikegawa S. Common variants in DWWA on chromosome 3p24.3 are associated with susceptibility to knee osteoarthritis. Nat Genet. 2008;40(8):994-8.

39. Meulenbelt I, Chapman K, Dieguez-Gonzalez R, Shi D, Tsezou A, Dai J, Malizos KN, Kloppenburg M, Carr A, Nakajima M, van der Breggen R, Lakenberg N, Gomez-Reino JJ, Jiang Q, Ikegawa S, Gonzalez A, Loughlin J, Slagboom EP. Large replication study and meta-analyses of DWWA as an osteoarthritis susceptibility locus in European and Asian populations. Hum Mol Genet. 2009:18(8):1518-23.

40. Mototani H, lida A, Nakajima M, Furuichi T, Miyamoto $Y$, Tsunoda T, Sudo A, Kotani A, Uchida A, Ozaki K, Tanaka Y, Nakamura Y, Tanaka T, Notoya K, Ikegawa S. A functional SNP in EDG2 increases susceptibility to knee osteoarthritis in Japanese. Hum Mol Genet. 2008;17(12):1790-7.

41. Chung HW, Seo JS, Hur SE, Kim HL, Kim JY, Jung JH, Kim LH, Park BL, Shin HD. Association of interleukin-6 promoter variant with bone mineral density in pre-menopausal women. J Hum Genet. 2003;48(5):243-8.

42. Giampietro PF, McCarty C, Mukesh B, McKiernan F, Wilson D, Shuldiner A, Liu J, LeVasseur J, Ivacic L, Kitchner T, Ghebranious N. The role of cigarette smoking and statins in the development of postmenopausal osteoporosis: a pilot study utilizing the Marshfield clinic personalized medicine cohort. Osteoporos Int. 2010;21(3):467-77.

43. Loh M, Koh KX, Yeo BH, Song CM, Chia KS, Zhu F, Yeoh KG, Hill J, lacopetta B, Soong R. Meta-analysis of genetic polymorphisms and gastric cancer risk: variability in associations according to race. Eur J Cancer. 2009;45(14):2562-8.

44. Valdes AM, Loughlin J, Oene MV, Chapman K, Surdulescu GL, Doherty M, Spector TD. Sex and ethnic differences in the association of ASPN, CALM1, COL2A1, COMP, and FRZB with genetic susceptibility to osteoarthritis of the knee. Arthritis Rheum. 2007;56(1):137-46.

45. Solovieva S, Vehmas T, Riihimaki H, Takala EP, Murtomaa H, Luoma K, LeinoArjas P. Finger osteoarthritis and differences in dental work tasks. J Dent Res. 2006;85(4):344-8.

46. Hämäläinen $S$, Solovieva $S$, Hirvonen A, Vehmas T, Takala EP, Riihimäk $H$, Leino-Arjas P. COL2A1 gene polymorphisms and susceptibility to osteoarthritis of the hand in Finnish women. Ann Rheum Dis. 2009; 68(10):1633-7.

47. Smith RL. Mechanical loading effects on articular cartilage matrix metabolism and osteoarthritis. In: Buckwalter JA, Lotz MK, Stolz JF, editors. Osteoarthritis, inflammation and degradation: a continuum. Amsterdam: IOS Press; 2007. p. 14-23.

48. Kou I, Nakajima M, Ikegawa S. Binding characteristics of the osteoarthritisassociated protein asporin. J Bone Miner Metab. 2010;28(4):395-402.

49. Miyamoto Y, Mabuchi A, Shi D, Kubo T, Takatori Y, Saito S, Fujioka M, Sudo A, Uchida A, Yamamoto S, Ozaki K, Takigawa M, Tanaka T, Nakamura Y, Jiang Q, Ikegawa S. A functional polymorphism in the 5' UTR of GDF5 is associated with susceptibility to osteoarthritis. Nat Genet. 2007;39(4):529-33.

50. Southam L, Rodriguez-Lopez J, Wilkins JM, Pombo-Suarez M, Snelling S, Gomez-Reino JJ, Chapman K, Gonzalez A, Loughlin J. An SNP in the 5'-UTR of GDF5 is associated with osteoarthritis susceptibility in Europeans and with in vivo differences in allelic expression in articular cartilage. Hum Mol Genet. 2007;16(18):2226-32.

51. Vaes RB, Rivadeneira F, Kerkhof JM, Hofman A, Pols HA, Uitterlinden AG, van Meurs JB. Genetic variation in the GDF5 region is associated with osteoarthritis, height, hip axis length and fracture risk: the Rotterdam study. Ann Rheum Dis. 2009;68(11):1754-60.

52. Valdes AM, Spector TD, Doherty S, Wheeler M, Hart DJ, Doherty M. Association of the DWWA and GDF5 polymorphisms with osteoarthritis in UK populations. Ann Rheum Dis. 2009;68(12):1916-20.

53. Valdes AM, Evangelou E, Kerkhof HJ, Tamm A, Doherty SA, Kisand K, Tamm A, Kerna I, Uitterlinden A, Hofman A, Rivadeneira F, Cooper C, Dennison EM, Zhang W, Muir KR, loannidis JP, Wheeler M, Maciewicz RA, van Meurs JB, Arden NK, Spector TD, Doherty M. The GDF5 rs143383 polymorphism is associated with osteoarthritis of the knee with genome-wide statistical significance. Ann Rheum Dis. 2011;70(5):873-5.

54. Valdes AM, Spector TD, Tamm A, Kisand K, Doherty SA, Dennison EM, Mangino M, Tamm A, Kerna I, Hart DJ, Wheeler M, Cooper C, Lories RJ, Arden NK, Doherty M. Genetic variation in the SMAD3 gene is associated with hip and knee osteoarthritis. Arthritis Rheum. 2010;62(8):2347-52.
55. van de Laar IM, Oldenburg RA, Pals G, Roos-Hesselink JW, de Graaf BM, Verhagen JM, Hoedemaekers YM, Willemsen $R$, Severijnen LA, Venselaar $H_{4}$ Vriend G, Pattynama PM, Collee M, Majoor-Krakauer D, Poldermans D, Frohn-Mulder IM, Micha D, Timmermans J, Hilhorst-Hofstee Y, BiermaZeinstra SM, Willems PJ, Kros JM, Oei EH, Oostra BA, Wessels MW, BertoliAvella AM. Mutations in SMAD3 cause a syndromic form of aortic aneurysms and dissections with early-onset osteoarthritis. Nat Genet. 2011; 43(2):121-6.

56. arcOGEN Consortium, arCOGEN Collaborators. Identification of new susceptibility loci for osteoarthritis (arCOGEN): a genome-wide association study. Lancet. 2012;380(9844):815-23.

57. Näkki A, Männikkö M, Saarela J. Genetic association and linkage studies in osteoarthritis. In Principles of Osteoarthritis- Its Definition, Character, Derivation and Modality-Related Recognition. Edited by Rothschild BM. SCRIBD, InTech. 2012;12:285-320. https://www.scribd.com/document/ 328699125/Principles-of-Osteoarthritis-Its-Definition-Character-Derivation-EtcB-Rothschild-Intech-2012-WW.

58. Cirulli ET, Goldstein DB. Uncovering the roles of rare variants in common disease through whole-genome sequencing. Nat Rev Genet. 2010;11(6):415-25.

\section{Submit your next manuscript to BioMed Central and we will help you at every step:}

- We accept pre-submission inquiries

- Our selector tool helps you to find the most relevant journal

- We provide round the clock customer support

- Convenient online submission

- Thorough peer review

- Inclusion in PubMed and all major indexing services

- Maximum visibility for your research

Submit your manuscript at www.biomedcentral.com/submit
C Biomed Central 